УДК 628.33:661.8

${ }^{[0000-0002-4608-4276]}$ Ю. В. Дзігора, аспірант,

${ }^{[0000-0001-5287-3733]}$ Г. С. Столяренко, д.т.н., професор, зав. кафедри ХТВ

Черкаський державний технологічний університет

б-р Шевченка, 460, м. Черкаси, 18006, Україна

\title{
МЕТОДИ РЕГЕНЕРАЦІЇ МЕМБРАН У СФЕРІ ОЧИЩЕННЯ СТІЧНОЇ ВОДИ
}

Мембранні технології набули значного поширення впродовж останніх років і мають всі шанси з часом замінити класичну систему очищення стічної води, яка вже не задовольняе потреб сучасного світу. Метод мембранного розділення за умови комбінування з попереднім біологічним очищенням характеризується високим ступенем очищення, стійкістю системи незалежно від фрлуктуачій навантаження, а також низьким впливом на довкілля. Серед усіх позитивних сторін все ж є кілька недоліків, серед яких основними є висока вартість і замулюваність мембран. Ці проблеми взаємопов'язані, тому, якщо вирішити проблему із замулюванням мембран, то висока вартість з часом окупиться. Завдяки сотням наукових досліджень у цьвому напрямі вдалося мінімізувати негативний вплив мембранного фоулінгу (від англ. fouling - замулення, обростання) та закупорення/замулення мембрани, щя впродовж довгого часу були основними лімітуючими факторами для широкого впровадження мембранних технологій. Для зниження лімітуючого впливу замулення на роботу мембрани можна регулювати ряд показників, включаючи гідродинамічний режим роботи, особливості експлуатації та очищення мембрани, якості та концентраиії вихідної води, а також, звісно, характеристик і матеріалу самих мембран.

Незважаючи на те, щзо методи для мінімізації фоулінгу розроблялися в різних напрямах, при розробиі правильного підходу можливе їх комбінування із значно кращим ефектом, наприклад, комбіноване очищення мембрани, що включає зворотне промивання, релаксацію та хімічне періодичне очищення. Впродовж останнього десятиліття мембранні технологій набули значного поширення, а їх впровадження у вже існуючі очисні споруди продовжує зростати в різних країнах світу, включаючи Швеиію, Китай, Сінгапур, США, Корею та ін. За умови ефективного інгібування обростання мембрани такі системи мають потениіал стати основними спорудами для очищення стічної води. Систематизовано основні методи очищення мембран - від класичних до останніх розробок сьогодення.

Ключові слова: мембранний біореактор, очищення мембран, методи очищення мембран, фоулінг, замулення мембран.

Вступ. Рівень забруднення поверхневих вод зростає в геометричній прогресії, виною тому є велика кількість стоків, які скидаються кожного дня в частково очищеному чи неочищеному стані. Термін «утилізація» переважно застосовується до банок, пластику, скла і паперу, але вода також може бути перероблена $[1,2]$. Повторне використання води може поліпшити сільськогосподарське виробництво: зменшити енергоспоживання, яке використовується для води, і збільшити видалення поживних речовин $[1,3]$. Крім того, щоб відновити стан екосистем, необхідно максимально зменшити вплив відходів, у тому числі й стічної води.

Проте існуюча традиційна система очищення стічної води не може впоратися 3 таким завданням. Сучасні проблеми потребують сучасних рішень. Мембранне розділення $\epsilon$ одним із можливих варіантів, здатних замінити класичні системи очищення, i для того було багато передумов (рисунок 1).

Серед переваг мембранного розділення можна відзначити [1]:

- простоту в обслуговуванні;

- стабільний вихідний потік води 3 високим ступенем очищення;

- невелику площу очисних споруд.

Метою дослідження було класифікувати існуючі методи для очищення мембран та зазначити особливості їх застосування.

1. Явище фоулінгу та закупорення/замулення мембрани

Незважаючи на всі переваги мембранного розділення, одними $з$ основних недоліків залишаються висока вартість мембран, примножена швидкістю їх обростання (fouling), та закупорення (clogging). Незважаючи на те, що 
обидва фактори впливають на зниження мембранної проникності, все ж їх варто розрізняти за фізичним значенням [5]:

- Обростання (англ. fouling) - покриття (обростання) мембранної поверхні чи забивання пор мембрани розчиненими, колоїдними чи дрібнодисперсними речовинами.
- Закупорення (англ. clogging) - агломерація високодисперсних речовин всередині чи на вході до мембранних каналів. Відкладення всередині каналів ще називають замуленням (англ. sludging).

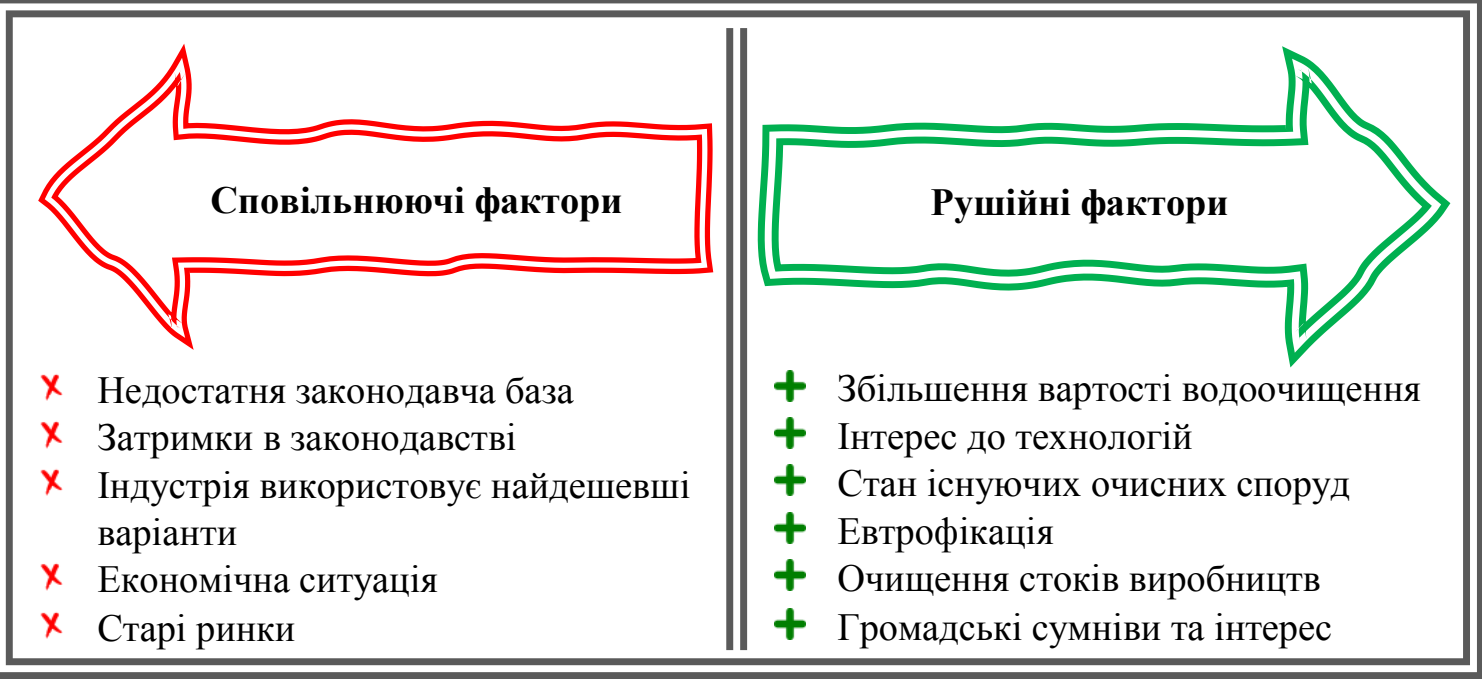

Рисунок 1 - Обмеження та рушійна сила для розвитку мембранних технологій [4]

Вчені переважно рухаються в таких напрямах для мінімізації негативних ефектів:

- вивчення властивостей та закономірностей обростання мембрани з метою пригнічення цього процесу;

- розробка мембран із нових матеріалів та покриттів для мембран; рації;

- оптимізація робочого режиму фільт-

- способи очищення мембран.

Для розуміння процесу фоулінгу та підбору найбільш ефективного методу очищення мембран необхідно виокремлювати наступні види фоулінгу (таблиця 1) [6].

Таблиця 1 - Види мембранного фоулінгу

\begin{tabular}{|l|l|c|l|}
\hline \multicolumn{2}{|c|}{ 1. За зворотністю процесу фоулінгу (залежно від часу утворення) } \\
\hline Вид фоулінгу & \multicolumn{1}{|c|}{ Фізичне значення } & $\begin{array}{l}\text { Час утво- } \\
\text { рення }\end{array}$ & \multicolumn{1}{|c|}{ Видалення } \\
\hline $\begin{array}{l}\text { Зворотний } \\
\text { (тимчасовий) }\end{array}$ & $\begin{array}{l}\text { Шар органічної речовини на } \\
\text { поверхні мембрани } 10 \text { хвилин }\end{array}$ & $\begin{array}{l}\text { Може бути видалений фізич- } \\
\text { ними/біологічними методами } \\
\text { очищення }\end{array}$ \\
\hline Незворотний & $\begin{array}{l}\text { Утворення більш міцних } \\
\text { структур на основі зворотного } \\
\text { шару, утворення так званого } \\
\text { гелевого шару, явище звужен- } \\
\text { ня та часткового блокування } \\
\text { пор тижні }\end{array}$ & $\begin{array}{l}\text { Видаляється хімічними чи } \\
\text { комбінованими методами, які } \\
\text { використовуються 3 метою пі- } \\
\text { дтримання процесу фільтрації }\end{array}$ \\
\hline Залишковий & $\begin{array}{l}\text { Сильні структури, що не ви- } \\
\text { даляються звичайними мето- } \\
\text { дами очищення }\end{array}$ & $\begin{array}{l}\text { ц-12 міся- } \\
\text { ців }\end{array}$ & $\begin{array}{l}\text { Видаляється методами хіміч- } \\
\text { ного інтенсивного очищення }\end{array}$ \\
\hline Постійний & $\begin{array}{l}\text { Перманентні відкладення в } \\
\text { порах мембран }\end{array}$ & Роки & Неможливо видалити \\
\hline
\end{tabular}


Продовження таблиці 1

2. За природою замуюючої речовини (залежно від природи вхідної води)

\begin{tabular}{|l|l|}
\hline Вид фоулінгу & \multicolumn{1}{|c}{ Фізичне значення } \\
\hline Органічний & $\begin{array}{l}\text { Відкладення органічних речовин, таких як полісахариди, білки, гумінові } \\
\text { кислоти тощо }\end{array}$ \\
\hline Біологічний & $\begin{array}{l}\text { Формується на поверхні мембрани внаслідок мікробіологічної діяльності, } \\
\text { що включає ріст, розвиток, формування колоній та мікробіологічні відкла- } \\
\text { дення на мембрані }\end{array}$ \\
\hline Неорганічний & $\begin{array}{l}\text { Неорганічні відкладення в результаті хімічного чи біологічного осадження } \\
\text { або утворення складних комплексів }\end{array}$ \\
\hline
\end{tabular}

3. За механізмом закупорення пор мембрани $[7,8]$ (залежно від характеристик потоку та співвідношення розміру частинок до діаметра пор)

\begin{tabular}{|l|l|l|l|}
\hline Назва & Зображення & Назва & 3ображення \\
\hline $\begin{array}{l}\text { 1. Повне бло- } \\
\text { кування } \\
\text { блокування }\end{array}$
\end{tabular}

Незалежно від того, наскільки добре організовано та оптимізовано процес очищення стічної води, після довгострокової фільтрації на мембрані з'являється фоулінг, який необхідно відповідно чистити. Фоулінг розвивається нерівномірно і поділяється на три етапи [8]:

- умовний фоулінг;

- постійний фоулінг;

- різкий фоулінг, що супроводжується різким стрибком трансмембранного тиску (ТМР) та відповідним зниженням мембранного проникнення.

Мінімізація фоулінгу є складною поліфакторною системою заходів, які базуються на:

- розмірі nор (найчастіше мікрофільтраційні й ультрафільтраційні мембрани), матеріалові (полімерні, керамічні, композитні мембрани) і формі (трубчасті та плоскі мембрани) мембран та їх модулів;

- гідродинамічному режимі мембранного проиесу (трансмембранний тиск, опір мембрани, мембранна проникність, швидкість потоку);

- природі води, щзо надходить, і характеристиках біомаси.

\section{2. Методи очищення мембран}

Мембрани можуть бути очищені різними методами, але всі їх можна об'єднати у чотири основні групи за механізмом очищення: фізичні, хімічні (реагентні), біологічні методи очищення та самоочисні мембрани зі спеціальними нанопокриттями (рисунок 2) [9].

Фізичні методи дають змогу впродовж довгого часу очищати мембрану від зворотного (тимчасового) фоулінгу, проте значно поступаються ефективністю хімічним методам очищення. Найчастіше використовуються гidравлічні методи, що включають зворотне промивання [10], релаксацію [11], а також вилучення агрегатів і частинок 3 поверхні мембрани за допомогою аерування [12].

У випадку, коли трансмембранний тиск досягає критичних значень, фізичного очищення вже недостатньо і проводиться хімічне очищення різними реагентами, залежно від природи відкладень на поверхні мембрани. Всі реагенти можна розділити на $[9,13]:$ кислоти (для видалення неорганічних відкладень), основи (для видалення органічних забрудників і контролю рівня $\mathrm{pH}$ ), оксиданти та дезінфектанти (для видалення органічних i 
біологічних речовин процесом окиснення або дезінфекції), інші та комбіновані реагенти.

Біологічні методи набули ширшого використання відносно недавно, i їх значною перевагою $\epsilon$ те, що мул в результаті біологічного осадження такими речовинами може використовуватися в агропромисловості як добриво, на відміну від хімічно осадженого мулу. Також біологічні реагенти взаємодіють лише 3 забрудниками, не руйнуючи самої мембрани. Для цього використовуються різного роду ферменти, які можна підбирати для кожного окремо взятого забрудника [14].

Інший метод - аеробне гранулювання процес утворення агрегатів шляхом іммобілізації внаслідок щільного розміщення клітин [15]. Руйнування енергетичного обміну дає змогу регулювати процес утворення біоплівки та запобігти обростанню мембрани. Для цього використовуються спеціальні інгібітори, які спричиняють від'єднання утворених агрегатів від поверхні мембрани. Також використовується так званий метод відчуття кворуму чи кворум-контроль. В основі цього методу лежить здатність певних бактерій та мікроорганізмів за рахунок секреції молекулярних сигналів координувати поведінку чи дії інших бактерій того ж підвиду [16].

Самоочисні «розумні» мембрани. Альтернативним методом очищення мембрани можна сміливо вважати покриття мембрани плівкою спеціальних речовин, що реагують на зміну зовнішнього середовища, змінюючи при цьому просторову конфігурацію сполук. Такі покриття дають можливість значно знизити рівень мембранного фоулінгу, не вдаючись при цьому до хімічних речовин (рисунок 2).

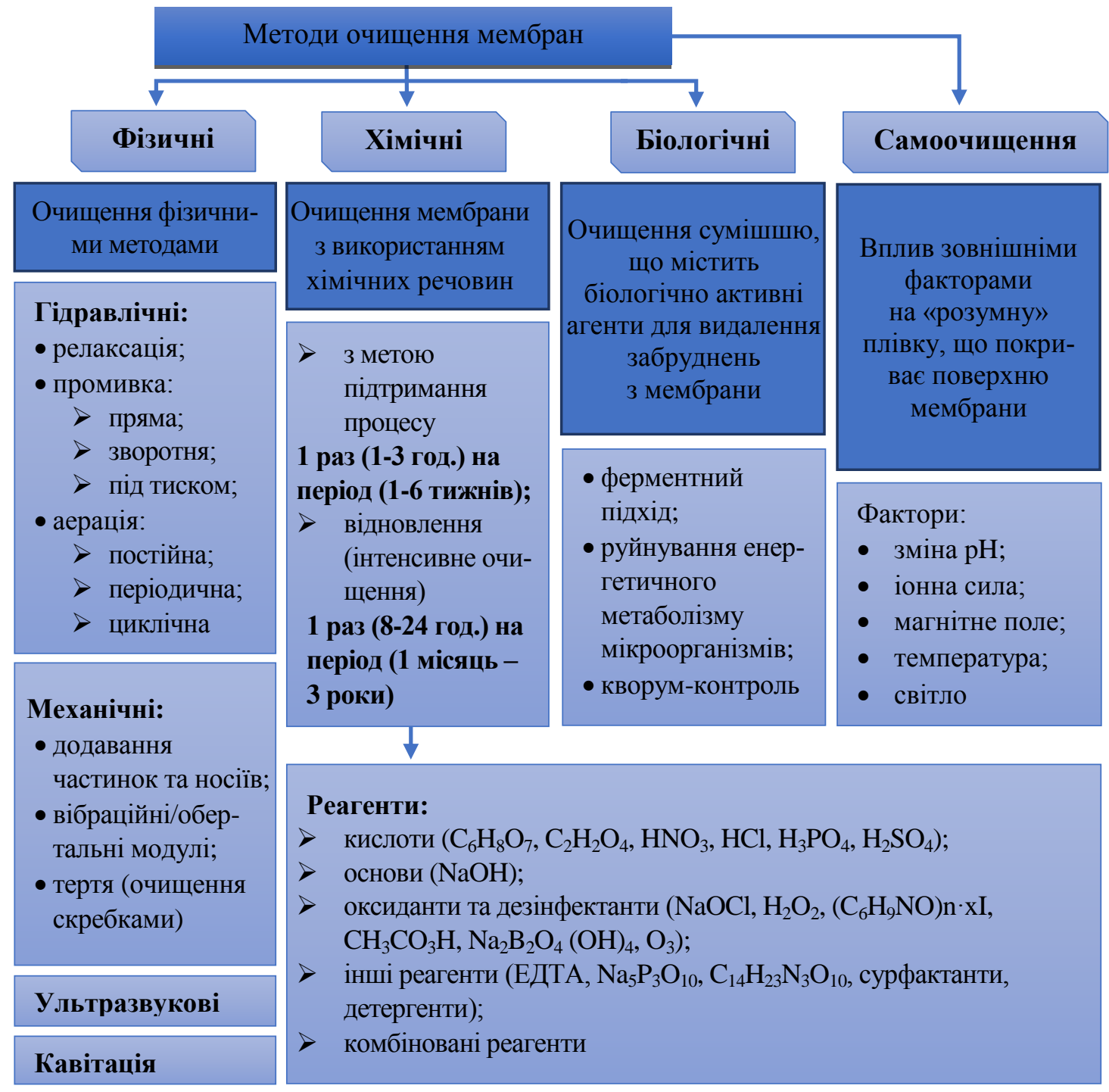

Рисунок 2 - Методи очищення мембран 
Залежно від типу зовнішнього фактора «розумні» поверхні можна розділити на ті, що реагують на:

- $\mathrm{pH}$;

- іонну силу;

- магнітне поле;

- температуру;

- світло (видиме світло й ультрафіолет).
Вплив цих факторів призводить до змін поверхневих характеристик мембрани і швидкості потоку води, що очищається. Тобто, наприклад, під впливом УФ світла сполуки, чутливі до нього, змінюють просторову конфігурацію, «струшуючи» всі агрегати, що приєдналися до поверхні мембрани (рисунок 3 ).

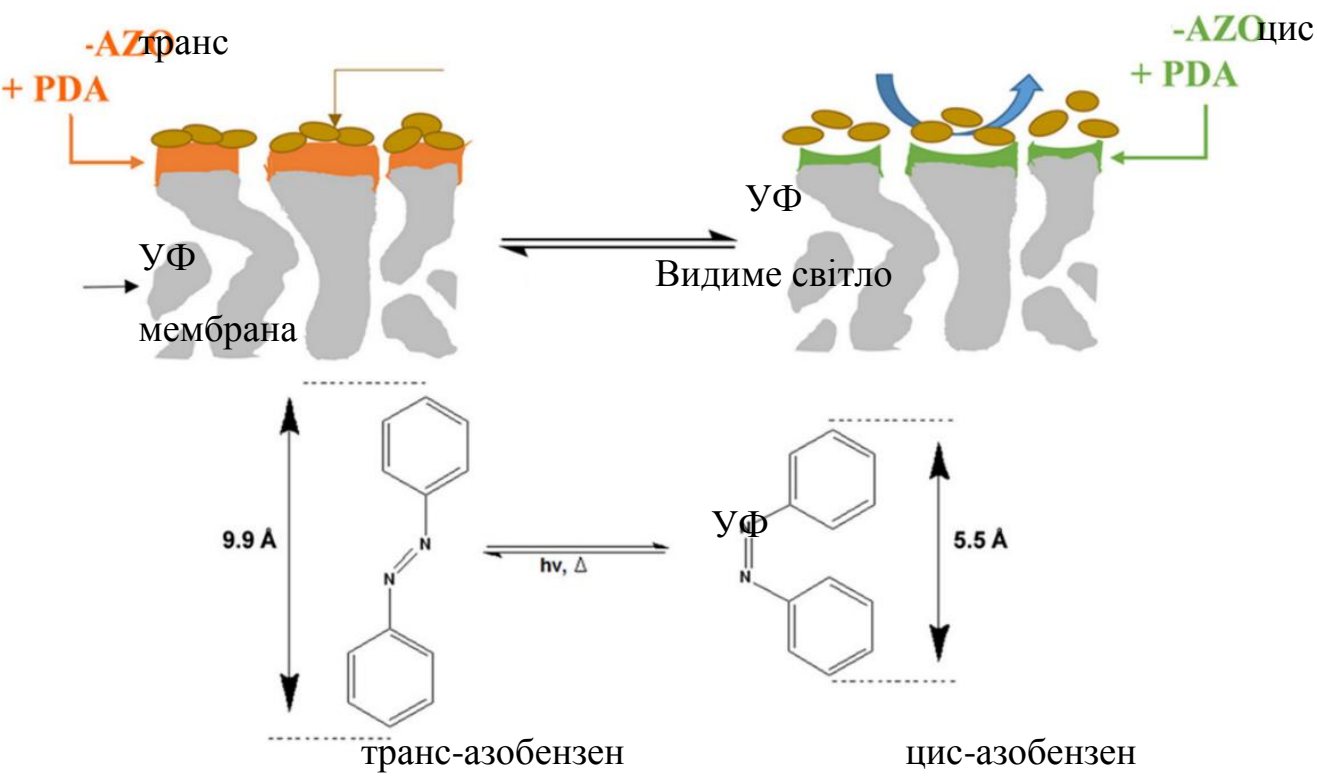

Рисунок 3 - Схематичне зображення процесу самоочищення мембрани під впливом ультрафіолету [17]

Висновки. Мембранні технології - це системи очищення зі значним потенціалом, які при правильному виборі оптимального режиму роботи здатні працювати впродовж довгого часу 3 максимальним рівнем ефективності. Основною проблемою цієї технології поки що є ціна та обростання/замулення мембран.

3 метою запобігання чи мінімізації фоулінгу мембран вченими було проведено багато досліджень, на базі яких сформовано систему методів, які при раціональному комбінуванні здатні дати максимальний ефект. Класифіковано існуючі методи для очищення мембран та визначено особливості їх застосування. Показано перспективність використання процесів самоочищення мембран. Визначено, що на цьому етапі розвитку науки в сфері мембранного розділення можливе ширше впровадження цієї технології.

\section{Список використаних джерел}

[1] Ю. В. Дзігора, "Комбіноване біомембранне очищення стічної води", на XVIII міжнар. наук.-практ. конф. Ресурси природних вод Карпатського регіону (Проблеми охорони та раціонального використання): зб. наук. статей (м. Львів, 2324 трав. 2019 р.). Львів: Нац. ун-т «Львівська політехніка», 2019, с. 117-118.

[2] US-EPA. Water Recycling and Reuse. Region 9: Water.

[3] US-EPA. Guidelines for Water Reuse. U.S. Agency for International Development.

[4] S. J. Judd, The MBR book - principles and applications of membrane bioreactors in water and wastewater treatment. Elsevier, 2006.

[5] The MBR site. MBR operation and maintenance - fouling, clogging and cleaning.

[6] A. Drews, "Membrane fouling in membrane bioreactors - characterisation, contradic- 
tions, cause and cures", Journal of Membrane Science, vol. 363 (1-2), pp. 1-28, 2010.

[7] P. Le-Clech, V. Chen, and T. A. G. Fane, "Fouling in membrane bioreactors used in wastewater treatment", Journal of Membrane Science, vol. 284 (1-2), pp. 1753, 2006.

[8] B. Ladewig, and M. N. Z. Al-Shaeli, "Fouling in Membrane Bioreactors", Fundamentals of Membrane Bioreactors: Materials, Systems and Membrane Fouling, 2017, pp. 29-85.

[9] Zhiwei Wang, Jinxing Ma, Chuyang Y. Tang, Katsuki Kimura, Qiaoying Wang, and Xiaomeng Han, "Membrane cleaning in membrane bioreactors: A review", Journal of Membrane Science, vol. 468, pp. 276-307, 2014.

[10] Yinghong Gaoa, Jie Qinb, Zhiwei Wangc, and Stein W. Østerhusa, "Backpulsing technology applied in MF and UF processes for membrane fouling mitigation: A review", Journal of Membrane Science, vol. 587, pp. 117-136, 2019.

[11] M. L. Christensen, T. V. Bugge, B. H. Hede, Marta Nierychlo, P. Larsen, and M. K. Jørgensen, "Effects of relaxation time on fouling propensity in membrane bioreactors", Journal of Membrane Science, vol. 504, pp. 176-184, 2016.

[12] M. Dalmau, H. Monclús, S. Gabarrón, I. Rodriguez-Roda, and J. Comasa, "Towards integrated operation of membrane bioreactors: effects of aeration on biological and filtration performance", Bioresource Technology, vol. 171, pp. 103-112, 2014.

[13] Yu. V. Dzihora, "Combination of moving bed biofilm reactor and membrane bioreactor for wastewater treatment", B Междунар. конф., посвящ. 145-летию УП «Минскводоканал», Современные тенденциии в развитии водоснабжения и водоотведения: в 2 ч. (г. Минск, 13-14 февр. 2019 г.). Минск: БГТУ, 2019, ч. 2, с. 147150.

[14] Chien-Hwa Yu, Lung-Chen Fang, Shaik Khaja Lateef, Chung-Hsin $\mathrm{Wu}$, and ChengFang Lin, "Enzymatic treatment for controlling irreversible membrane fouling in cross-flow humic acid-fed ultrafiltration",
Journal of Hazardous Materials, vol. 177 (1-3), pp. 1153-1158, 2010.

[15] Majid Bagheri, and Sayed Ahmad Mirbagheri, "Critical review of fouling mitigation strategies in membrane bioreactors treating water and wastewater", Bioresource Technology, vol. 258, pp. 318334, 2018,

[16] Xiaolei Zhang, Kibaek Lee, Huarong Yu, Naresh Mameda, and Kwang-Ho Choo, "Photolytic quorum quenching: A new antibiofouling strategy for membrane bioreactors", Chemical Engineering Journal, vol. 378, 2019.

[17] Sankara Narayanan Ramanan, Nima Shahkaramipour, Thien Tran, Lingxiang Zhu, Surendar R. Venna, Chang-Keun Lim, Ajay Singh, Paras N. Prasad, and Haiqing Lin, "Self-cleaning membranes for water purification by co-deposition of photomobile 4,4'-azodianiline and bio-adhesive polydopamine", Journal of Membrane Science, vol. 554, pp. 164-174, 2018.

\section{References}

[1] Yu. V. Dzihora, "Combined biomembrane wastewater treatment", in $18^{\text {th }}$ Int. Sci.Pract. Conf. Resources of natural waters of the Carpathian region (Problems of protection and rational use). Lviv: Nats. un-t «Lvivska politekhnika», 2019, pp. 117-118 [in Ukrainian].

[2] US-EPA. Water Recycling and Reuse. Region 9: Water.

[3] US-EPA. Guidelines for Water Reuse. U.S. Agency for International Development.

[4] S. J. Judd, The MBR book - principles and applications of membrane bioreactors in water and wastewater treatment. Elsevier, 2006.

[5] The MBR site. MBR operation and maintenance - fouling, clogging and cleaning.

[6] A. Drews, "Membrane fouling in membrane bioreactors - characterisation, contradictions, cause and cures", Journal of Membrane Science, vol. 363 (1-2), pp. 1-28, 2010.

[7] P. Le-Clech, V. Chen, and T. A. G. Fane, "Fouling in membrane bioreactors used in wastewater treatment", Journal of 
Membrane Science, vol. 284 (1-2), pp. 1753, 2006.

[8] B. Ladewig, and M. N. Z. Al-Shaeli, "Fouling in Membrane Bioreactors", Fundamentals of Membrane Bioreactors: Materials, Systems and Membrane Fouling, 2017, pp. 29-85.

[9] Zhiwei Wang, Jinxing Ma, Chuyang Y. Tang, Katsuki Kimura, Qiaoying Wang, and Xiaomeng Han, "Membrane cleaning in membrane bioreactors: A review", Journal of Membrane Science, vol. 468, pp. 276-307, 2014.

[10] Yinghong Gaoa, Jie Qinb, Zhiwei Wangc, and Stein W. Østerhusa, "Backpulsing technology applied in MF and UF processes for membrane fouling mitigation: A review", Journal of Membrane Science, vol. 587, pp. 117-136, 2019.

[11] M. L. Christensen, T. V. Bugge, B. H. Hede, Marta Nierychlo, P. Larsen, and M. K. Jørgensen, "Effects of relaxation time on fouling propensity in membrane bioreactors", Journal of Membrane Science, vol. 504, pp. 176-184, 2016.

[12] M. Dalmau, H. Monclús, S. Gabarrón, I. Rodriguez-Roda, and J. Comasa, "Towards integrated operation of membrane bioreactors: effects of aeration on biological and filtration performance", Bioresource Technology, vol. 171, pp. 103-112, 2014.

[13] Yu. V. Dzihora, "Combination of moving bed biofilm reactor and membrane bioreactor for wastewater treatment", in Int.
Conf. dedicated to the $145^{\text {th }}$ anniversary of Minskvodokanal Unitary Enterprise. Current Trends in the Development of Water Supply and Sanitation: materials of the: in 2 parts. Minsk: BGTU, 2019, part 2, pp. 147-150.

[14] Chien-Hwa Yu, Lung-Chen Fang, Shaik Khaja Lateef, Chung-Hsin $\mathrm{Wu}$, and ChengFang Lin, "Enzymatic treatment for controlling irreversible membrane fouling in cross-flow humic acid-fed ultrafiltration", Journal of Hazardous Materials, vol. 177 (1-3), pp. 1153-1158, 2010.

[15] Majid Bagheri, and Sayed Ahmad Mirbagheri, "Critical review of fouling mitigation strategies in membrane bioreactors treating water and wastewater", Bioresource Technology, vol. 258, pp. 318334, 2018,

[16] Xiaolei Zhang, Kibaek Lee, Huarong Yu, Naresh Mameda, and Kwang-Ho Choo, "Photolytic quorum quenching: A new antibiofouling strategy for membrane bioreactors", Chemical Engineering Journal, vol. 378, 2019.

[17] Sankara Narayanan Ramanan, Nima Shahkaramipour, Thien Tran, Lingxiang Zhu, Surendar R. Venna, Chang-Keun Lim, Ajay Singh, Paras N. Prasad, and Haiqing Lin, "Self-cleaning membranes for water purification by co-deposition of photomobile 4,4'-azodianiline and bio-adhesive polydopamine", Journal of Membrane Science, vol. 554, pp. 164-174, 2018.

Yu. V. Dzihora, Ph. D. student,

H. S. Stolyarenko, D. Tech. Sc., professor, head of the department of chemical technology and water treatment

Cherkasy State Technological University

Shevchenko blvd, 460, Cherkasy, 18006, Ukraine

\section{MEMBRANE REGENERATION METHODS IN WASTEWATER TREATMENT}

Membrane technologies have become widespread in recent years and have a big chance of eventually replacing the classic wastewater treatment system that no longer meets the needs of the modern world. The method of membrane separation, combined with previous biological treatment, is characterized by a high degree of purification, stability of the system irrespective of load fluctuations, and low environmental impact. However, there are several disadvantages among all the positives, the main ones being the high cost and the membrane fouling. These problems are interrelated, so if you 
solve the problem of membrane fouling, then the high cost will pay off over time. Hundreds of scientific studies in this field have succeeded in minimizing the negative effects of membrane fouling and clogging/sludging, which have long been the main limiting factors for widespread introduction of membrane technologies. To reduce the limiting effect of fouling on the membrane, a number of indicators can be adjusted, including hydrodynamic mode, peculiarities of membrane operation and purification, quality of feeding water and concentration of impurities, and characteristics and material of the membranes.

Although the techniques for minimizing fowling have been developed in different directions, when developing the right approach, they can be combined with a much better effect, for example, combined membrane purification, including backwashing, relaxation, and chemical periodic treatment. In the last decade, membrane technologies have become widespread, and their introduction into existing wastewater treatment plants continues to grow in various countries all over the world, including Sweden, China, Singapore, the United States, Korea, and others. Provided effective inhibition of membrane fouling, such systems have the potential to become the main wastewater treatment plants. In the review article the basic methods of membranes purification-from classical to the recent developments - are systematized.

Keywords: membrane bioreactor, membrane purification, methods of membrane purification, fouling, membrane fouling.

Стаття надійшла 14.01.2020

Прийнято 05.02.2020 